\title{
Intrinsic and specific groundwater vulnerability using the GOD method as a pre-operational baseline assessment of an unconventional hydrocarbon industry
}

\section{Gustavo Filemon Costa Lima ( $\square$ gustavofilemon2@gmail.com )}

Centre for Development of Nuclear Technology: Centro de Desenvolvimento da Tecnologia Nuclear https://orcid.org/0000-0003-3793-4395

Vinícius Gonçalves Ferreira

Federal University of Minas Gerais: Universidade Federal de Minas Gerais

Jussara da Silva Diniz Lima

Federal University of Minas Gerais: Universidade Federal de Minas Gerais

Joyce Castro de Menezes Duarte

Centre for Development of Nuclear Technology: Centro de Desenvolvimento da Tecnologia Nuclear

Ana Cecília Dufilho

Universidad Nacional del Comahue

Carlos Alberto de Carvalho Filho

Centre for Development of Nuclear Technology: Centro de Desenvolvimento da Tecnologia Nuclear

\section{Research Article}

Keywords: Groundwater vulnerability of the São Francisco basin, Shale gas in the São Francisco basin, GOD groundwater vulnerability assessment, Unconventional Hydrocarbons.

Posted Date: March 30th, 2021

DOI: https://doi.org/10.21203/rs.3.rs-274642/v1

License: (c) (i) This work is licensed under a Creative Commons Attribution 4.0 International License. Read Full License 


\section{Abstract}

In the middle of the São Francisco basin, the sub-basins of Indaia and Borrachudo river highlight the considerable potential for unconventional hydrocarbon exploration. The present study seeks to evaluate the groundwater resource's intrinsic and specific vulnerability in the Indaiá and Borrachudo basins as an environmental baseline study for further development in the shale gas industry. The overlay and index GOD method was applied to assess the aquifer's intrinsic susceptibility regarding the Groundwater confinement $(\mathrm{G})$, the Overlying Strata $(0)$, and the Depth of the groundwater table (D). The specific vulnerability assessment considered the intrinsic vulnerability and the land cover/use of the area, concerning the diversity and the toxicity of pollutants inherent in each anthropogenic activity. The results indicate that $52.69 \%, 25.12 \%$, and $17.57 \%$ of the aquifer area have Medium, High, and Extreme intrinsic vulnerability, respectively. The specific vulnerability assessment suggests an overall vulnerability reduction due to the low anthropogenic stress on the basin. Three gas research wells overlay moderate intrinsic vulnerability. One well is above the high vulnerability area, which concerns how the unconventional industry could develop regarding groundwater susceptibility in this ecosystem.

\section{Introduction}

Aquifers can be sensitive to surface anthropogenic activities; therefore, evaluating the vulnerability of groundwater resources is crucial in the implementation of new strategies on environmental monitoring and conservation (Oliveira et al. 2020). The need to delineate specific policies towards the underground water supply regarding sustainable development is a world consensus. Nowadays, Brazil retains $12 \%$ of the planet's freshwater resources (ANA, 2020), requiring special attention to the conservation and protection of those waters.

The São Francisco hydrographic basin is one of Brazil's most relevant water resources, covering $8 \%$ of the national territory. It is responsible for the water supply of 521 municipalities in six federal units (Torres et al. 2019). Environmental studies focused on the vulnerability of water resources are fundamental to the country's strategic and sustainable development regarding this region's socioeconomic relevance Considering the São Francisco basin context, the Indaiá River and the Borrachudo River are significant drainage areas with extreme potential in many economic activities (Fig. 1). These subbasins are one of the main poles of fish farming in the country; it has a growing development of the agricultural activities and cattle ranching; and it has mineral resources applicable in stonemeal techniques. The Indaiá and Borrachudo basins also emerge as a strategic area for the potential exploitation of unconventional hydrocarbon reserves. Intensive prospective research for unconventional gas exploration was being conducted in this area until the Brazilian public prosecutor's office decided to stop those activities under the pretext of the lack of environmental background to guarantee safety and clarity concerning this economic practice (Camargo et al. 2014; FGV, 2018).

The controversial processes of unconventional gas exploration can lead to various influxes of contaminants into local aquifers through the use of hydraulic fracturing techniques (fracking). These flows can be classified into two groups: Ascendant Flows - coming from the deep rock strata (unconventional gas reservoirs) towards the aquifers (e.g., failure to cement the gas wells; induction of connectivity between fractures) and Descendant Flows - the contamination comes from the surface and infiltrates through the soils and surficial water bodies until it reaches the groundwater pools (e.g. spills, leaks, and/or the disposal of inadequately treated shale gas wastewater) (Vidic et al. 2013; Vengosh et al. 2014). The relationship between the unconventional hydrocarbon industry and water resource quality is conflicting, thus triggering an intense public debate about how the environmental and regulatory policies should be conducted (Vengosh et al. 2014).

In this context, the R\&D project, GASBRAS (Research and Development Network in Non Conventional Gas in Brazil), proposed the assessment of intrinsic and specific vulnerability of groundwater resources in the Indaiá and Borrachudo basins. This research provides an environmental baseline of aquifers regarding the potential unconventional hydrocarbon industry development in the São Francisco basin. Therefore, the objectives of this work are: (1) to evaluate the intrinsic vulnerability of aquifers by applying the GOD method (Foster, 1987) - an overlay and index mapping technique adapted for 
large areas with low data background (Ghazavi and Ebrahimi 2015), (2) to establish the specific vulnerability of aquifers regarding land use and soil management criteria, and (3) to elucidate the susceptibility of local aquifers to a potential unconventional hydrocarbon industry development.

\subsection{Study area}

The Indaiá and Borrachudo watershed cover 4,488 $\mathrm{km}^{2}$ and are responsible for twelve cities' water supply, including an overall population of approximately 90,000 inhabitants. The climate in the study area is defined as an Ay-type (Koppen classification), describing a typical rainy tropical environment with two well-defined seasons: a wet summer from October to February and a dry winter from March to September (Trindade et al. 2018). There is a predominance of cambisol soils followed by latosols and litholic soils (Fig. 2). According to the Brazilian Agricultural Research Company (EMBRAPA), different climate conditions and protolith sources provide significant heterogeneity in the cambisol textures. The latosols are deep ( $>2 \mathrm{~m}$ ), non-hydromorphic soils, with B horizons higher than $50 \mathrm{~cm}$, with a clay content between $15 \%$ and $80 \%$ (EMBRAPA, 2020). Litholic soils (neossols) show rocky surface strata overlaid directly on the rock or in the saprolite.

\subsection{Geology and Hydrogeology}

The study area consists of the San Francisco craton domain, in a polyhistoric environment with sedimentary Neoproteozoic formation (Bambuí Group) below the phanerozoic formations (Areado and Mata da Corda Group) (Dardene et al. 1997; Fragoso et al. 2011; Reis, 2018). The Bambuí Group sedimentation is formed in a marine paleoenvironment by the sequence of metapelites (Serra de Santa Helena Formation and Serra da Saudade Formation) and carbonates (Sete Lagoas Formation and Lagoa do Jacaré Formation), overlapped by siliciclastic units and arcosean sandstones (Três Marias Formation). A second depositional stage is represented by the Areado Group (conglomerates, clays, and sandstones) and by volcano-sedimentary and ultramafic alkaline intrusions of the Mata da Corda Group (Fig. 3A). This lithological diversity contributes to distinctive hydrodynamic behaviors in the study area, classified into different groundwater systems.

Groundwater systems include two or more lithologies and aquifers according to their similarities in water dynamics. These were classified according to the geology (Fig. 3B), following the classification criteria proposed by the Geological Survey of Brazil (CPRM, 2019). Five aquifer systems were defined in the study area: I) Detritic and Alluvial Coverage System corresponding to the tertiary-quaternary cover deposits whose specific yield discharge and hydraulic transmissivity in the river courses are in the order of $10^{-2} \mathrm{~m}^{3} / \mathrm{s} / \mathrm{m}$ and $10^{-6} \mathrm{~m}^{2} / \mathrm{s}$, respectively. In higher altimetric zones, it can reach the order of $0.026 \mathrm{~m}^{3} / \mathrm{h} / \mathrm{m}$ and $1.7 \times 10^{-6} \mathrm{~m}^{2} / \mathrm{s}$, respectively; II) Arenitic-system - associated with cretaceous sandy rocks of the Areado and Mata da Corda groups. The specific yield discharge and the transmissivity in this system are close to 0.77 $\mathrm{m}^{3} / \mathrm{h} / \mathrm{m}$ and $3.6 \times 10^{-4} \mathrm{~m}^{2} / \mathrm{s}$, respectively; III) Arcosean-Silt-Sandstone- the siltstones and fine sandstones of the Três Marias formation (Bambuí Group) with a specific yield discharge and a transmissivity close to $0.19 \mathrm{~m} / \mathrm{h} / \mathrm{m}$ and $4.5 \times 10^{-}$ ${ }^{5} \mathrm{~m}^{2} / \mathrm{s}$, respectively; IV) Pelític-Carbonate System - The pelitic-carbonated units of the Serra da Saudade and Serra de Santa Helena formations of the Bambuí Group. The specific yield discharge and transmissivity are $0.44 \mathrm{~m} 3 / \mathrm{h} / \mathrm{m}$ and $7.2 \times 10^{-}$

${ }^{5} \mathrm{~m}^{2} / \mathrm{s}$, respectively. V) Carbonate system - Limestones and dolomites from the Lagoa do Jacaré and Sete Lagoas formations, both from the Bambuí Group. In this system, the specific yield discharge and transmissivity are around 4.4 $\mathrm{m}^{3} / \mathrm{h} / \mathrm{m}$ and $8.7 \times 10^{-4} \mathrm{~m}^{2} / \mathrm{s}$, respectively.

The underground flow lines presented in Fig. 3B were inserted in the groundwater systems map based on the potentiometric levels registered in the well's data. These lines aim to highlight the regional underground water flows by following the topography. However, the authors consider that due to the amount of data, further studies will be necessary to assess the groundwater flow dynamics.

\subsection{Land use/cover}


The agropastoral activity and the natural vegetation areas (areas without direct anthropogenic modifications) are predominant in the Indaiá and Borrachudo basins. Figure 1 describes nine kinds of land use/cover, where three categories are natural environments and six are anthropogenic activities. The Grassland, Savanna, and Forest formations compose the natural vegetation ground cover, totaling $1,881 \mathrm{~km}^{2}$ that are well distributed throughout the study area. The grazing areas and animal husbandry vary from subsistence to intensive cattle raising, covering $2,323 \mathrm{~km}^{2}$ with greater prominence in the center-south portions. Forestry occupies $86 \mathrm{~km}^{2}$ of the study area and is primarily practiced in the Northwest, near the Três Marias reservoir. The perennial farming (mostly corn and sorgos) covers $36 \mathrm{~km}^{2}$. Areas of urban infrastructure and small mines have also been reported in the region (emphasis on stonemeal exploitation for fertilizers). Table 1 detailed the characteristics of each local anthropic activity.

Table 1

Type of ground cover and land use

\begin{tabular}{|c|c|c|c|}
\hline Classes & $\begin{array}{l}\text { Area } \\
\left(\mathrm{km}^{2}\right)\end{array}$ & $\%$ & Description \\
\hline $\begin{array}{l}\text { Forest } \\
\text { Formation }\end{array}$ & 708 & 16 & $\begin{array}{l}\text { The predominance of arboreal species, with a continuous canopy formation (Riparian } \\
\text { Forest, Gallery Forest, Dry Forest, and Cerradão) (Ribeiro and Walter, 2008), besides } \\
\text { semi-deciduous seasonal forests (vegetation belonging to the Atlantic Forest biome } \\
\text { (Inland Atlantic Forest), and occasionally in the Cerrado). }\end{array}$ \\
\hline $\begin{array}{l}\text { Savanna } \\
\text { Formation }\end{array}$ & 723 & 16 & $\begin{array}{l}\text { Savanna formations with defined arboreal and shrub-herbaceous strata [Cerrado } \\
\text { Sentido Restrito (dense Cerrado, typical Cerrado, drained Cerrado, and rupestrian } \\
\text { Cerrado) and Cerrado Park]. }\end{array}$ \\
\hline $\begin{array}{l}\text { Forest } \\
\text { Plantation }\end{array}$ & 86 & 2 & Arboreal species planted for commercial purposes (e.g. eucalyptus, pine, araucaria) \\
\hline Grassland & 449 & 10 & $\begin{array}{l}\text { Grassland with predominance of herbaceous stratum (dirty field, clean field, and rock } \\
\text { field) }\end{array}$ \\
\hline Pasture & 2,323 & 52 & Areas of pasture, natural or planted, linked to agricultural activity. \\
\hline $\begin{array}{l}\text { Annual and } \\
\text { Perennial } \\
\text { Crop }\end{array}$ & 36 & 1 & Areas predominantly occupied with annual crops \\
\hline $\begin{array}{l}\text { Urban } \\
\text { Infrastructure }\end{array}$ & 1 & 0 & $\begin{array}{l}\text { Urbanized areas with a predominance of non-vegetated surfaces, including roads and } \\
\text { construction work. }\end{array}$ \\
\hline Mining & 0.01 & 0 & $\begin{array}{l}\text { Areas related to large mineral extraction, with clear exposure of the soil due to the } \\
\text { action of heavy machinery. }\end{array}$ \\
\hline $\begin{array}{l}\text { Other non } \\
\text { vegetable } \\
\text { area }\end{array}$ & 35 & 1 & Not applicable \\
\hline $\begin{array}{l}\text { River and } \\
\text { Lake }\end{array}$ & 125 & 3 & Rivers, lakes, reservoirs, and other water bodies. \\
\hline Total & 4,487 & 100 & \\
\hline
\end{tabular}

\section{Methodology}

GOD method (Foster, 1987) consists of evaluating groundwater's intrinsic vulnerability regarding three conjugated criteria: Groundwater confinement (G) (ranging from free to confined); O - Overlying strata, and D - the depth to water resources. Each parameter receives a score from 0 to 1 and then multiplied to yield a final GOD index (Fig. 4). 
The final GOD index can be classified as negligible (0 to 0.1$)$, low (0.1 to 0.3$)$, moderate (0.3 to 0.5$)$, high ( 0.5 to 0.7$)$, and extreme (0.7 to 1$)$. The higher scores denote greater susceptible groundwater vulnerability.

The GOD method's choice considered the large extension of the study area and the lack of lithological and pedological data in high spatial resolution. In this context, GIS tools, data processing techniques, and geostatistical methods were applied to evaluate groundwater vulnerability. The GOD index definition crossed the lithological, pedological, topographic, hydrographic, and tubular well data, both from different sources (Table 2). All data procedures were managed using ArcGIS 10.2.2 from the Environmental Systems Research Institute (ESRI)®.

Table 2

Background data used to calculate the GOD index.

\begin{tabular}{|lll|}
\hline Data & Function & Reference \\
\hline $\begin{array}{l}\text { Digital Elevation Model (30m } \\
\text { spatial resolution) }\end{array}$ & Altimetry and drainage characterization & USGS (2020) \\
\hline Ottobasin System & Definiton of the basin extension & ANA (2020) \\
\hline Tubular well data & $\begin{array}{l}\text { Data treatment of soil type information, groundwater } \\
\text { confinement, and depth. }\end{array}$ & $\begin{array}{l}\text { SIAGAS (2020) and } \\
\text { SIAM (2017) }\end{array}$ \\
\hline Lithological map (1:100.000) & Geological and groundwater system mapping & CODEMIG (2010) \\
\hline Pedological (1:650.000) & Pedological mapping & IDE-Sisema (2020) \\
\hline
\end{tabular}

\subsection{G Index - Groundwater Confinement}

The "G" parameter contemplates the degree of confinement of each aquifer (Table 3). The "G" rating considered the groundwater systems based on the similarity of the hydrogeological behavior of the units (hydraulic transmissivity and specific yield discharge), as well as the regional groundwater confinement defined for each system by the Brazilian Geological Survey (CPRM, 2019).

The alluvial aquifer area was demarcated using a buffer of $300 \mathrm{~m}$ from the Indaiá and Borrachudo rivers and 150 meters for their respective tributaries, assuming both as unconfined systems. It was possible to validate and adjust the $G$ index scores by checking the registered wells' geological profiles.

Table 3

- G rating based on groundwater systems

\begin{tabular}{|lllll|}
\hline $\begin{array}{l}\text { Groundwater } \\
\text { system }\end{array}$ & $\begin{array}{l}\text { Hydraulic Transmissivity } \\
\left(\mathbf{m}^{2} / \text { day) }\right.\end{array}$ & $\begin{array}{l}\text { Specific yield discharge } \\
\left(\mathbf{m}^{3} / \mathbf{s} / \mathbf{m}\right)\end{array}$ & $\begin{array}{l}\text { Degree of } \\
\text { Confinement }\end{array}$ \\
\hline Laterite Soil & 0.0864 & 0.01 & Semi-unconfined & 0.4 \\
\hline Alluvial Deposits & 0.1469 & 0.026 & Unconfined & 0.7 \\
\hline Sandstones & 31.104 & 0.77 & Unconfined & 0.8 \\
\hline $\begin{array}{l}\text { Arkosic- } \\
\text { sandstones }\end{array}$ & 3.888 & 0.19 & Unconfined & 0.7 \\
\hline Pelitic-Carbonates & 6.221 & 0.44 & Unconfined & 0.6 \\
\hline Carbonates & 75.168 & & (covered) & Unconfined \\
\hline
\end{tabular}




\subsection{Index - Overlying Strata}

The "O" criterion values the type of lithology above the groundwater level regarding the layers' contaminant retention capacity. Bambuí, Mata da Corda, Areado groups, and Quaternary sediments were adopted with different 0 Index values.

In the surrounding Três Marias reservoir, the pedological map was used as the dominant overlying strata due to the water level's proximity to the surface. The association between the geological map and the pedological map resulted in five classes with a different $\mathrm{O}$ index (Table 4 and Fig. 4).

Table 4

O parameter evaluation based on geological and pedological maps.

\begin{tabular}{|llc|}
\hline Litotypes & Geological units & Note O \\
\hline Arkosic-sandstones-siltsones & Três Marias Formation (Bambuí Group) & 0.6 \\
\hline Alluvial deposits & Quaternary sediments & 0.9 \\
\hline Latossols & Pedogenic layer in shallow unconfined groundwater systems & 0.7 \\
\hline Sandstones & Areado and Mata da Corda Group & 0.8 \\
\hline Pelitic-Carbonates & Serra da Saudade, Serra de Santa Helena Formations (Bambuí Group) & 0.9 \\
\hline Carbonates & Lagoa do Jacaré and Sete Lagoas Formation (Bambuí Group) & 1.0 \\
\hline
\end{tabular}

\subsection{Index - Depth of the Groundwater Table}

The $\mathrm{D}$ Index considers the distance between the surface and the groundwater table, quantified by a value between 0.6 and 1.0. It is assumed that the more profound the groundwater level, the lower the groundwater vulnerability (Fig. 4). The occurrences of sedimentary carbonate rocks bring out the specific dynamics of karst flow; hence, it receives a maximum value (1.0).

The groundwater table was settled by interpolating tubular well data and the perennial drains inside the Borrachudo and Indaiá rivers using ArcGIS. The tubular well data also confirm where the semi-confined groundwater systems are. In this case, the roof of the layer was used for the interpolation instead of the well's static water level.

\subsection{Intrinsic vulnerability (GOD)}

The GOD intrinsic vulnerability assessment multiplies three indexes (G - Groundwater confinement; O - Overlying strata; D Depth of the groundwater table) to yield a final GOD index. The GOD value interpolation results in an intrinsic groundwater vulnerability map.

\subsection{Specific vulnerability (GODs)}

The intrinsic vulnerability represents the overall susceptibility of aquifers to be affected by contaminants from the surface, considering the geological, hydrological, and hydrogeological settings (Ghazavi and Ebrahimi 2015). Specific vulnerability complements the intrinsic vulnerability by assessing contamination risks based on contaminants' nature and anthropic activities developed on the surface (Gogu and Dassargues 2000).

The different land use/cover was evaluated regarding their respective potential contaminants that might spread there (Fig. 1). The diversity and the toxicity of pollutants inherent to each type of anthropic activity defined the risk assessment index (Table 5). According to their toxicity, the risk index involves ranking substances quantified by a range from 0.0 to 1.0 . Therefore, following the overlay and index methodology, the intrinsic vulnerability map of aquifers (GOD) was combined with the risk assessment to generate a specific vulnerability map (GODs). 
Table 5

Risk values for each type of land use/cover

\begin{tabular}{|c|c|c|}
\hline Land use/cover & Potential Pollutants & $\begin{array}{l}\text { Risk } \\
\text { Index }\end{array}$ \\
\hline Mining & Heavy metals, Oils and Greases, and Acids & 1.0 \\
\hline Urban Infrastructure & Sewage, Industrial Effluents, and Oils and Greases & 0.9 \\
\hline $\begin{array}{l}\text { Forest Plantation and Annual and } \\
\text { Perennial Crop }\end{array}$ & Pesticides and Fertilizers & 0.7 \\
\hline Pasture & Fecal Coliform and Antibiotics & 0.6 \\
\hline Grassland & $\begin{array}{l}\text { Fecal Coliform and Antibiotics (This formation may include } \\
\text { pasture areas) }\end{array}$ & 0.2 \\
\hline $\begin{array}{l}\text { Savanna Formation and Forest } \\
\text { Formation }\end{array}$ & Not applicable & 0.1 \\
\hline
\end{tabular}

The risks index range varies from 0.0 to 1.0, representing the lowest and highest risk of contamination, respectively. The specific vulnerability map (GODs) maintained the grade intervals of the intrinsic vulnerability, according to the classification in Table 6.

Table 6

GODs values and corresponding classes of vulnerability

\begin{tabular}{|ll|}
\hline Specific vulnerability classes* & GODs Index \\
\hline Negligible & $<0.1$ \\
\hline Low & $0.1-0.3$ \\
\hline Medium & $0.3-0.5$ \\
\hline High & $0.5-0.7$ \\
\hline Extreme & $>0.7$ \\
\hline *The GODs index range was proposed by the authors of this research \\
\hline
\end{tabular}

\section{Results And Discussion}

\subsection{Intrinsic vulnerability assessment - GOD}

The three maps corresponding to the three parameters of the GOD method are exposed in Fig. 5 . The three maps show the propensity of the zones proximal to the dam to present higher vulnerability indexes.

The GOD Index assessment yields an intrinsic vulnerability map (Fig. 6A). Each GOD class and its respective area (\%) is shown in Table 7. It may be observed that Medium, High, and Extreme classes are predominant in the Indaiá and Borrachudo basin. Low vulnerability corresponds to $4.62 \%$. These areas correlate with a higher degree of confinement and the presence of the Três Marias formation (sandstones-siltstones) near the reservoir. Medium vulnerability represents $52.69 \%$, covering most of the middle-south of the basins under analysis. High and extreme vulnerability areas majorly concentrate in the reservoir's surrounding areas and alluvial systems, corresponding to $25.12 \%$ and $17.57 \%$, respectively. There are no areas of negligible intrinsic vulnerability. The Três Marias reservoir extension was excluded in the intrinsic 
vulnerability assessment. Fig. 5 The three index mapping used according to the GOD methodology: (a) G - Groundwater confinement; (b) O - Overlying strata, and (c) D - Depth to the groundwater table.

It is also essential to observe that due to the large extension of the basins, the classes with a relatively smaller coverage on the map still correspond to a significant territorial extension area (e.g., the low vulnerability class occupies $4.62 \%$ of the basin and represents $197.29 \mathrm{~km}^{2}$ of the area).

The south-central portion of the GOD map shows a predominant variation between the medium and high degree of vulnerability. The relatively small depth of the water table and the overlying lithotypes conditioned a context of higher susceptibility. The northern portion of the basin has a mostly high and extreme intrinsic vulnerability, both fostered by layers of fine soil and the water table closest to the surface. There is a low vulnerability zone near the reservoir conditioned by the Latosols (Fig. 3). The alluvial aquifers are linked to the main drainages of the basin. These systems have an extreme vulnerability, justified by the composition of unconsolidated sediments and by the shallow groundwater water table.

Table 7

\begin{tabular}{|lll|}
\multicolumn{3}{l}{ - Coverage areas of each GOD class } \\
\hline GOD classes & Area $\left(\mathrm{km}^{2}\right)$ & $\%$ \\
\hline Low & 197.29 & 04.62 \\
\hline Medium & $2,248.34$ & 52.69 \\
\hline High & $1,071.76$ & 25.12 \\
\hline Extreme & 749.51 & 17.57 \\
\hline Total & $\mathbf{4 , 2 6 6 . 9}$ & $\mathbf{1 0 0 . 0 0}$ \\
\hline
\end{tabular}

\subsection{Specific vulnerability assessment - GODs}

When the anthropic activities and the nature of the contaminants are taken into account, the specific vulnerability map showed a general reduction in the vulnerability classes as compared to the GOD map (Fig. 6B). An expected result, once the natural vegetation and extensive small/medium-sized livestock are predominant in the basin, both activities with a relatively low impact on groundwater resources.

Due to their high susceptibility to the presence of contaminants, alluvial aquifers were outlined as areas of extreme vulnerability. Higher vulnerabilities are concentrated in the reservoir's vicinity, highlighting the expressive pastoral activity (Fig. 1) in places of considerable intrinsic vulnerability in GOD assessment.

The mining areas and urban infrastructure might have a significant impact on groundwater systems. However, those activities have small spatial coverage in the basin. It overlays low intrinsic vulnerability zones, so it did not elevate the specific vulnerability to those areas. Each GODs class and its respective area (\%) is shown in Table 8. 
Table 8

Coverage areas of each GODs

classes

\begin{tabular}{|lll|}
\hline Classe & Area $\left(\mathbf{k m}^{2}\right)$ & $\%$ \\
\hline Negligible & $1,309.31$ & 30.79 \\
\hline Low & $1,593.14$ & 37.46 \\
\hline Medium & 611.11 & 14.37 \\
\hline High & 11.91 & 0.28 \\
\hline Extreme & 726.99 & 17.10 \\
\hline Total & $\mathbf{4 , 2 5 2 . 4 6}$ & 100.00 \\
\hline
\end{tabular}

Negligible and low specific vulnerability corresponds to $30.79 \%$ and $37.46 \%$ of the basin, respectively. The areas of Medium specific vulnerability correspond to $14.37 \%$. High and extreme vulnerability corresponds to $0.28 \%$ and $17.10 \%$, respectively. The groundwater systems from Indaiá and Borrachudo basins overall have a lower risk of contamination, regarding the current social and economic settings of the area. However, the alluvial systems and the surroundings of the Três Marias reservoir contrast due it higher specific vulnerability, and this should be taken into account in medium-term socio-economic development planning.

\subsection{Groundwater vulnerability and the unconventional hydrocarbon resources}

Four research wells for unconventional hydrocarbons are currently installed in the Indaiá and Borrachudo basin (Fig. 1). The areas of exploration and production of unconventional gas are prone to generate inflows descending from harmful contaminants to aquifers, either by the production and processing operations of commodities or by the presence of intensive machinery and infrastructure elements of the exploration.

The GOD mapping demonstrates that the three southern gas wells overlap the Medium intrinsic vulnerability zones. The fourth gas well in the northeast, on the other hand, is in a high intrinsic vulnerability area, nearby the alluvial groundwater system. It alerts as to how the activity could be developed without resulting in environmental hazards to groundwater resources. The GODs mapping shows that the northernmost gas well is above a specific medium-high vulnerability area, which implies a region that is more susceptible to human activities, which highlights the possibility of contamination coming from other anthropogenic sources.

The intrinsic and specific vulnerability elaborated here only concerns the flows of pollutants originating from the surface that can infiltrate and reach the aquifers, thus not encompassing the other possible routes of upward or lateral contamination of the exploitation of unconventional gas.

\section{Conclusions}

Using the GOD overlay and index methodology, the intrinsic and specific vulnerability of aquifers in the Indaiá and Borrachudo rivers basins, two major potential areas for the exploitation of natural unconventional gas, was evaluated. The area showed a predominance of classes of medium and high intrinsic vulnerability in all its extensions, with the most susceptible areas being concentrated near the Três Marias reservoir, where there is a relatively higher concentration of anthropic activities. The smaller groundwater table depth from the surface concomitantly with the structural-geological carbonate context leads to a higher susceptibility to water resources around the reservoir. Specifically, the alluvial aquifers have an extreme intrinsic vulnerability in all their extension, highlighting the susceptibility of the surrounding areas of the Indaiá and Borrachudo rivers. On the other hand, the predominance of areas of natural vegetation and areas of incipient 
anthropic impacts predominantly appeared on a map with low and negligible specific vulnerability, with the exception of the northern locations, where economic activities and the environmental context increase the risk of contamination.

Three gas wells for unconventional hydrocarbons are located in a medium intrinsic vulnerability area, and one gas well is above a high intrinsic vulnerability area. Both of them are relatively close to the alluvial aquifers (extreme vulnerability), highlighting the need for greater caution if economic activity expands there.

The Indaiá and Borrachudo basins are an area of strategic socioeconomic relevance, and regarding the low volume of geological-environmental background data available prior to this study, the GOD vulnerability assessment brings early insights about the spatial potentialities and susceptibilities concerning these groundwater resources. GOD and GODs provided crucial information for the monitoring and development of anthropic development, and it could represent the first step toward yielding a preoperational environmental baseline for unconventional hydrocarbon exploration in those basins.

\section{Declarations}

\section{ACKNOWLEDGMENT}

The authors are grateful to the Studies \& Projects Sponsorships (FINEP) for the support in the development of this research; The Nuclear Technology Development Center (CDTN) for their laboratory assistance; National Institute of Science and Technology Acqua - Mineral resources, Water and Biodiversity/Federal University of Minas Gerais (INCTAcqua/UFMG) for their logistical support; Universidad National del Comahue (UNCo), and the researcher, Ana Cecilia Dufilho, for her excellent academic assistance.

FUNDING: The Studies \& Projects Sponsorships (FINEP) (Financiadora de Estudos e Projetos, FINEP) financed the GASBRAS Project, within the scope of which this research was developed.

CONFLICTS OF INTEREST: The authors declare that they have no known competing financial interests or personal relationships that could have appeared to influence the work reported in this paper.

\section{References}

ANA - Agência Nacional de Águas (2010) https://www.ana.gov.br/noticias-antigas/brasil-tem-cerca-de-12-das-reservasmundiais-de-a.2019-03-15.1088913117. Accessed 20 February 2020.

Camargo TRM de, Merschmann PR de C, Arroyo EV, Szklo A (2014) Major challenges for developing unconventional gas in Brazil - Will water resources impede the development of the Country[U+05F3]s industry? Resour Policy 41:60-71.

https://doi.org/10.1016/j.resourpol.2014.03.001

CPRM - Cândido, M; Beato, D; Fiume, B; Scudino, P; Carneiro, F; Nascimento, F; Coutinho, M; Almeida, C; Socorro, A; Santana, M; Ribeiro, R; Cordeiro, B. (2019) Projeto Águas do Norte de Minas - PANM: Estudo da Disponibilidade Hídrica Subterrânea do Norte de Minas Gerais. Relatório de Integração. Serviço Geológico do Brasil (CPRM). p 1-222

Companhia de Desenvolvimento Econômico de Minas Gerais - CODEMIG (2011) Sistema de Informações Geográficas de Mapeamentos Geológicos em Folhas na escala de 1:100.000 pelo Projeto Alto Paranaíba. Disponível em http://www.portalgeologia.com.br/index.php/mapa/. Accessed 01 July 2020.

Dardenne, M. A. (1997). As Relações Entre Os Grupos Bambuí e Vazante na Faixa Brasília. ANAIS-ACADEMIA BRASILEIRA DE CIENCIAS, 69, 288-288.

Dassargues, A, Gogu, RC (2000) Current trends and future challenges in groundwater vulnerability assessment using overlay and index methods. Environmental geology, 39(6), 549-559. 
Mendoza JA, Barmen G (2006) Assessment of groundwater vulnerability in the Río Artiguas basin, Nicaragua. Environ Geol 50:569-580. https://doi.org/10.1007/s00254-006-0233-1.

EMBRAPA - Empresa Brasileira de Pesquisa Agropecuária (2020). Sistema Brasileiro de Classificação de Solos. (2001) https://www.agencia.cnptia.embrapa.br/gestor/bioma_caatinga/arvore/CONT000g798rt3o02wx5ok0wtedt3n5ubswf.html. Accessed 20 February 2020.

EMBRAPA - Empresa Brasileira de Pesquisa Agropecuária (2020). Sistema Brasileiro de Classificação de Solos. https://ainfo.cnptia.embrapa.br/digital/bitstream/item/93143/1/sistema-brasileiro-de-classificacao-dos-solos2006.pdf> Accessed 28 April 2020.

Fernandes LFS, Cardoso LVRQ, Pacheco FAL, et al (2014) DRASTIC and GOD vulnerability maps of the Cabril River Basin, Portugal. Rem Rev Esc Minas 67:133-142. https://doi.org/10.1590/s0370-44672014000200002.

FGV - Fundação Getúlio Vargas (2018) Projeto Poço Transparente: Testes para reservatórios de baixa permeabilidade Gerando conhecimento via avaliação ambiental prévia estratégica. FGV Energia, Brasil.

Fragoso, D. G. C., Uhlein, A., Sanglard, J. C. D., Suckau, G. L., Guerzoni, H. T. G., \& Faria, P. H. (2011). Geologia dos grupos Bambuí, Areado e Mata da Corda na folha Presidente Olegário (1: 100.000), MG: registro deposicional do Neoproterozóico ao Neocretáceo da Bacia do São Francisco. Geonomos. https://doi.org/10.18285/geonomos.v19i1.60.

Foster, S. (1987) Fundamental concept in aquifer vulnerability pollution risk and protec- tion strategy. Proc. Intl. Conf. Vulnerability of soil and groundwater to pollution Nordwijk, The Nether-lands, April.

Ghazavi R, Ebrahimi Z (2015) Assessing groundwater vulnerability to contamination in an arid environment using DRASTIC and GOD models. Int J Environ Sci Technol 12:2909-2918. https://doi.org/10.1007/s13762-015-0813-2

IDE-Sisema - Infraestrutura de Dados Espaciais do Sistema Estadual de Meio Ambiente e Recursos Hídricos (2020). Disponível em http://idesisema.meioambiente.mg.gov.br/. Accessed 01 July 2020.

MAPABIOMAS (2018) Uso e cobertura do solo. Ano 2018. Disponível em: https://mapbiomas.org/en/download Acesso em 05 de maio de 2020.

Reis, H. L. S (2018) Gás natural. In: Pedrosa-Soares, A. C.; Voll, E.; Cunha, E. C. (Eds.). Recursos Minerais de Minas Gerais. Belo Horizonte: Companhia de Desenvolvimento de Minas Gerais (CODEMGE), p. 1-39.

Ribeiro, J. F., \& Walter, B. M. T. (2008) As principais fitofisionomias do bioma Cerrado. Cerrado: ecologia e flora, 1, 151-212. SIAGAS - Sistema de Informações de Águas Subterrâneas (2020) http://siagasweb.cprm.gov.br/layout. Accessed 16 April 2020.

Sistema Integrado de Informação Ambiental. SIAM (2017) http://www.siam.mg.gov.br/siam/login.jsp. Accessed 04 April 2020.

Torres I, Horn A, Lemos R (2019) Metal dynamics in a tropical watershed: The São Francisco river and its compartments. Geochim Bras 33:221-233. https://doi.org/10.21715/gb2358-2812.2019332221.

Trindade WM, Horn AH, Aranha PRA, et al (2018) Evironmental evaluation of the middle São Francisco River basin between Três Marias and Pirapora , using chemical and geophysical investigation in sediment profiles from selected marginal lagoons. Geochim Bras 32:79-87. Disponível em https://doi.org/10.21715/GB2358-2812.2018321079. 
Tuller, M and Silva, J. (2002) Projeto São Francisco. Projeto integrante do programa Levantamentos Geológicos Básicos do Brasil. Serviço Geológico do Brasil (CPRM).

USGS - United States Geological Survey (2020) Earth Resources Observation and Science (EROS) Center. USGS EROS Archive - Digital Elevation - Shuttle Radar Topography Mission (SRTM) Non-Void Filled. Disponível em:

<https://www.usgs.gov/centers/eros/science/usgs-eros-archive-digital-elevation-shuttle-radar-topography-mission-srtmnon?qt-science_center_objects=0\#qt-science_center_objects>. Accessed 10 February 2020

Vengosh A, Jackson RB, Warner N, et al (2014) A Critical Review of the Risks to Water Resources from Unconventional Shale Gas Development and Hydraulic Fracturing in the United States. Environ Sci Technol.

Vidic RD, Brantley SL, Vandenbossche JM, et al (2013) Impact of Shale Gas Development on Regional Water Quality. Science (80-) 340:. https://doi.org/10.1126/science.1235009.

\section{Figures}

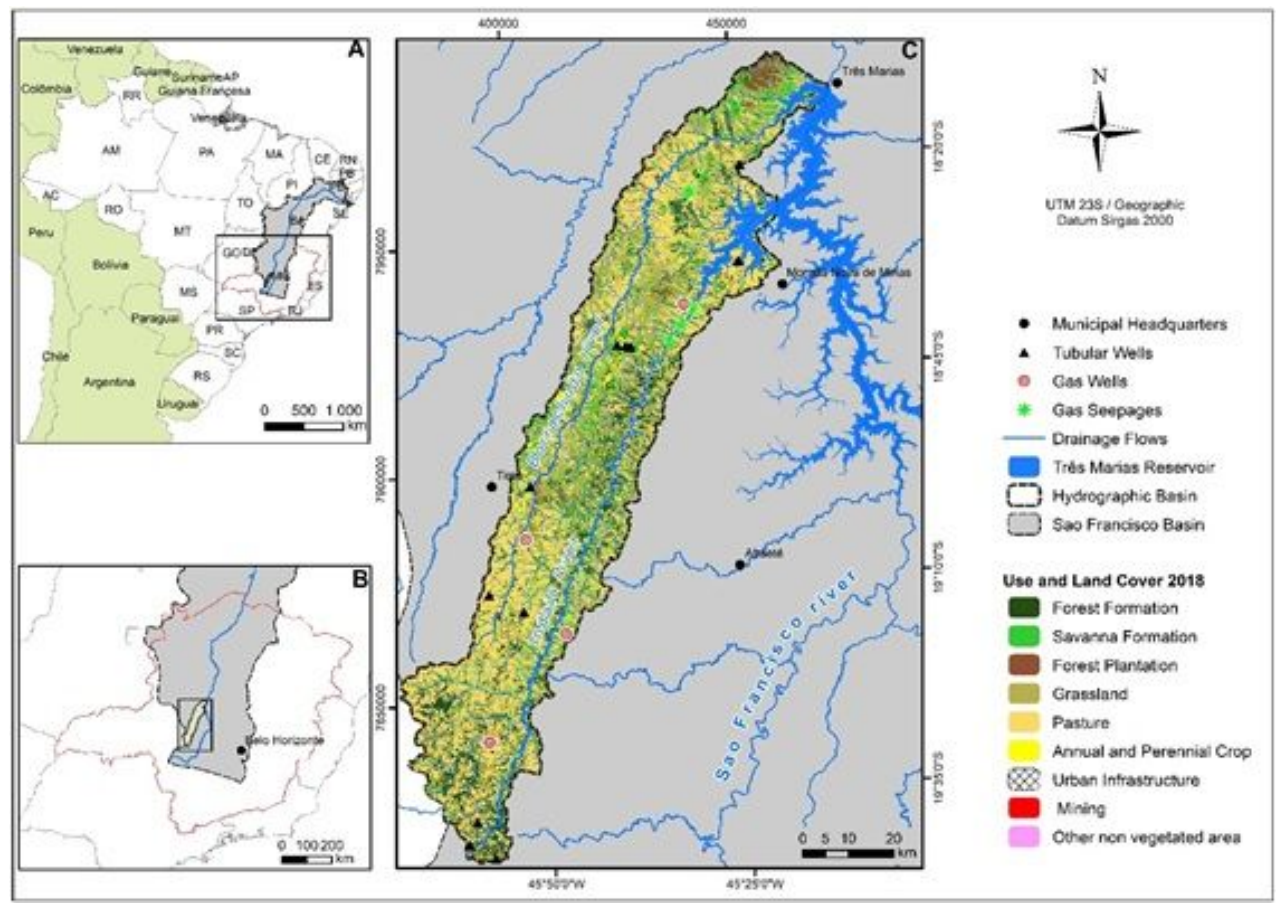

Figure 1

Location map of the study area and the type of land use/cover. A - Location of the San Francisco Hydrographic basin in Brazil and South America; B - Indaiá and Borrachudo Hydrographic Basins in the Upper São Francisco Basin context within the State of Minas Gerais; and C - Indaiá and Borrachudo Hydrographic Basins. (Mapabiomas, 2018). 


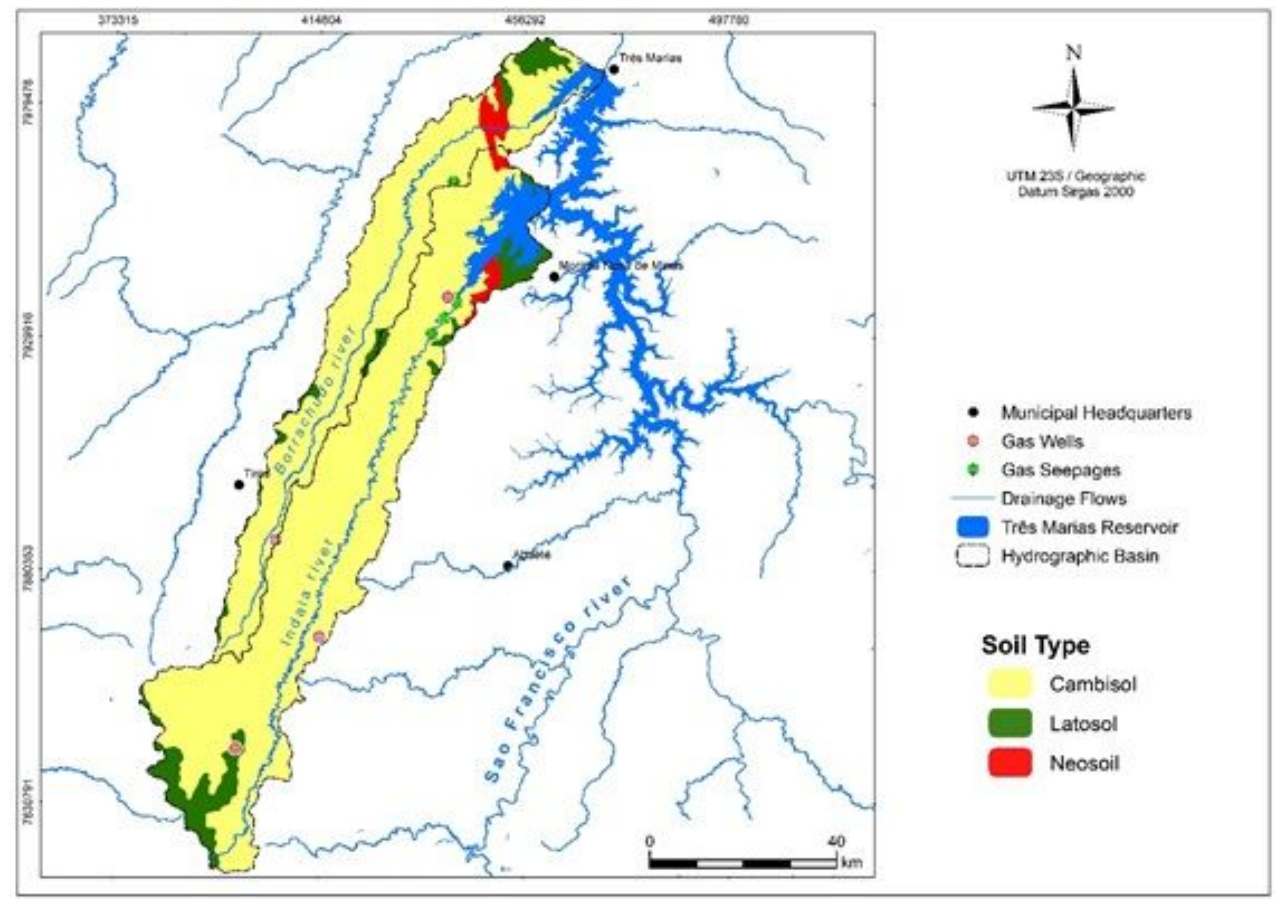

Figure 2

Pedological map of the Indaiá and Borrachudo Hydrographic Basins. Adapted from (IDE-Sisema, 2020).

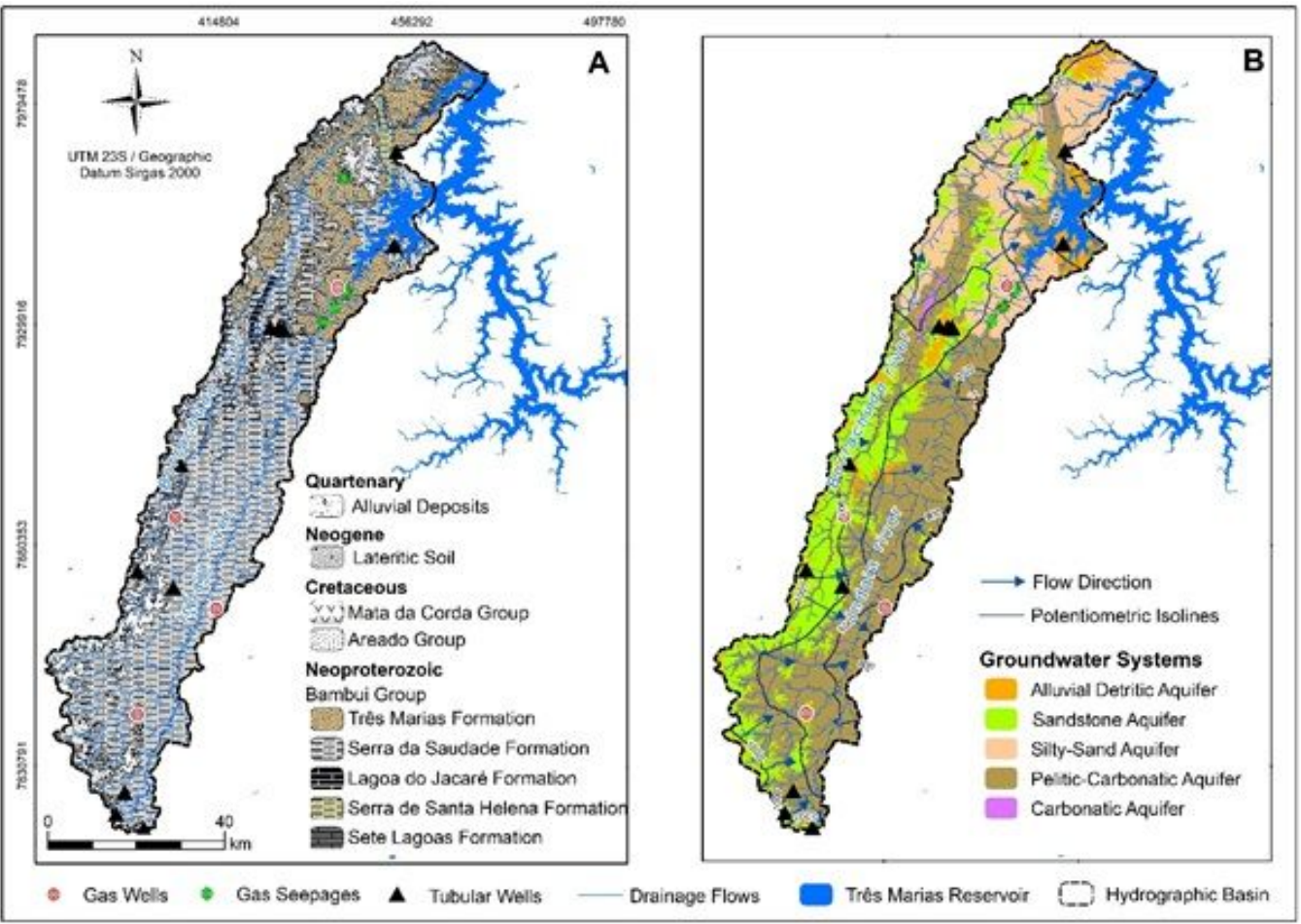

Figure 3

(A) Geological map of the Indaiá and Borrachudo basins. (B) Groundwater Systems. (IDE-Sisema, 2020) 


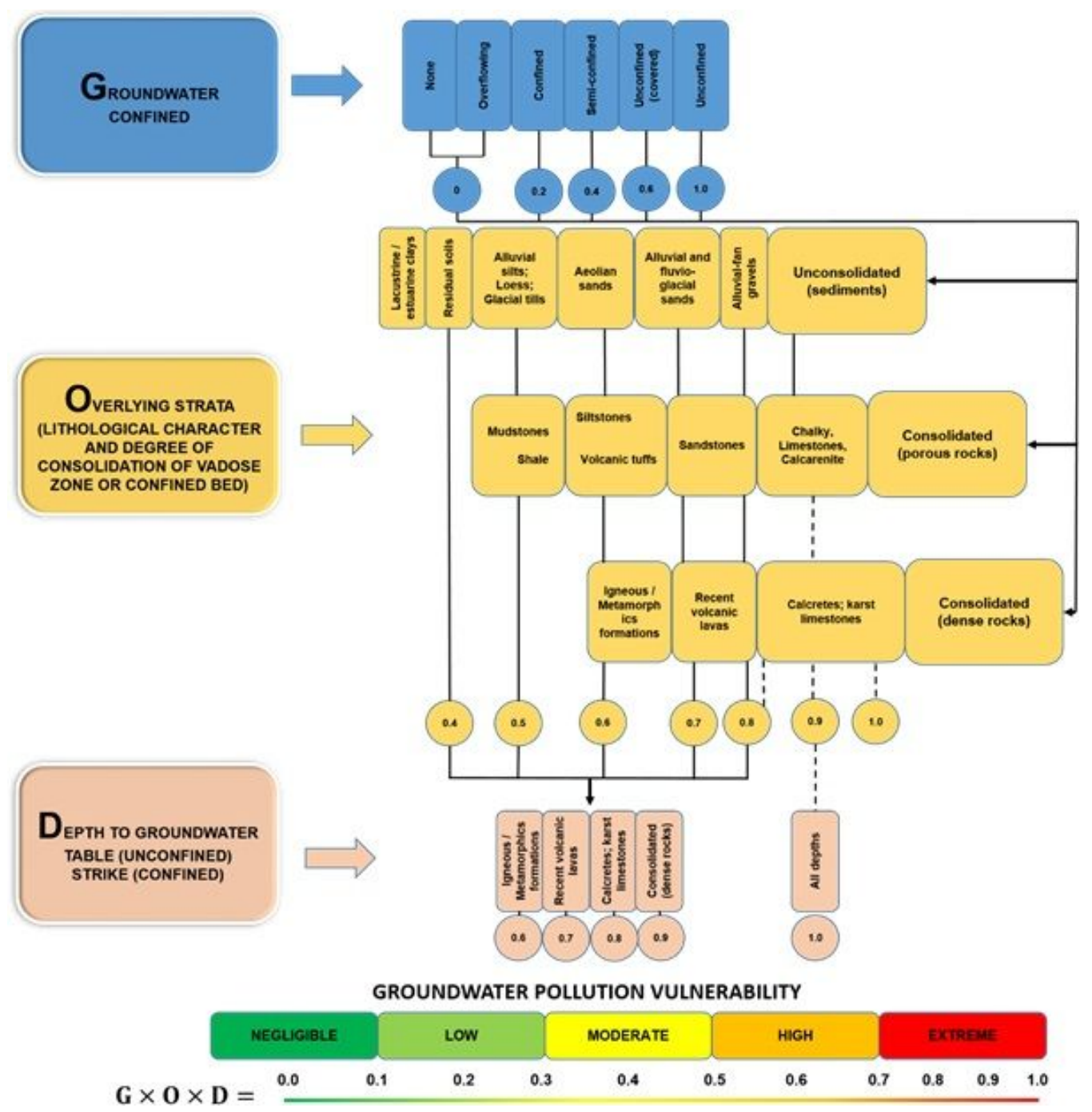

Figure 4

Vulnerability assessment by GOD methodology (Foster 1987; Modified from Mendoza and Barmen 2006).

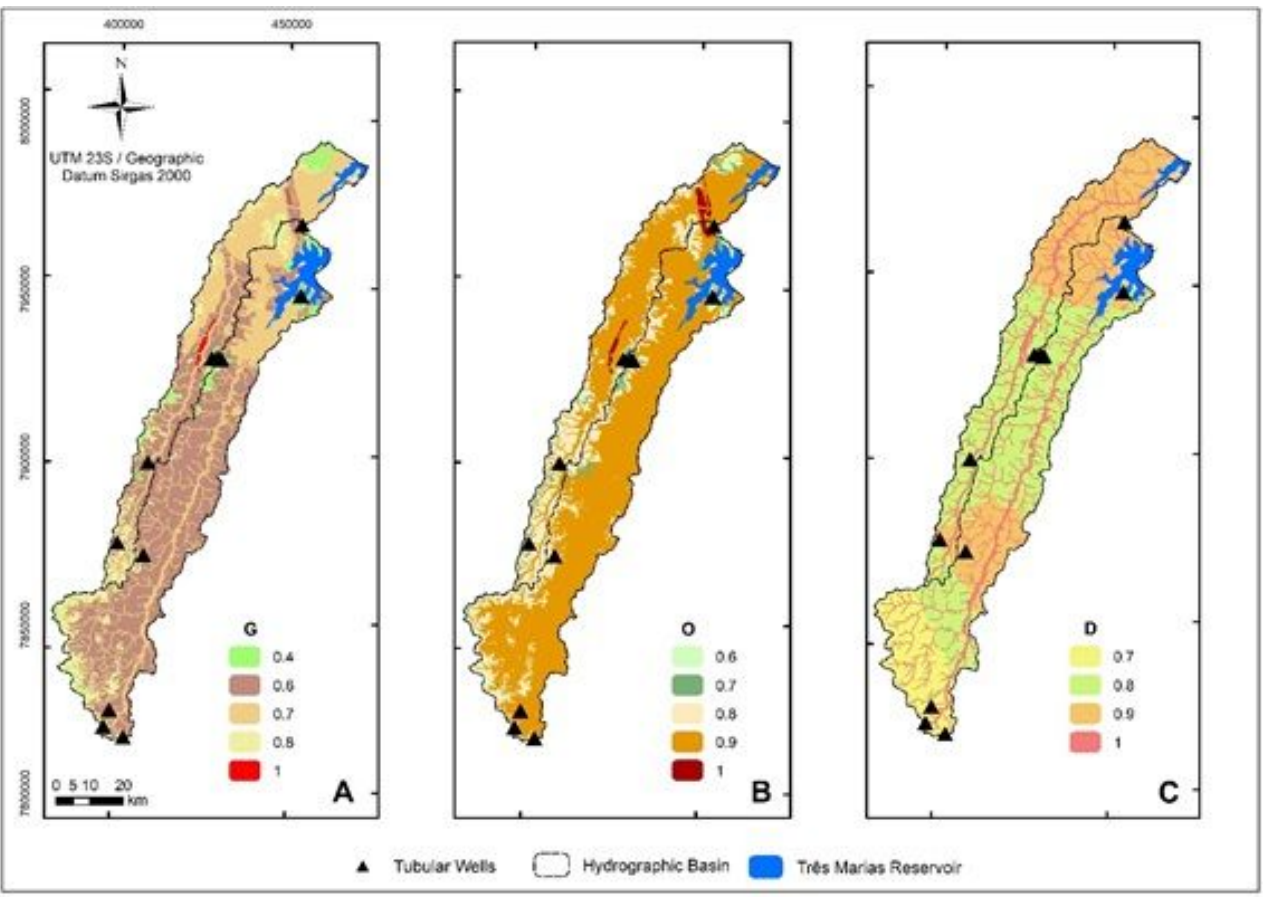


Figure 5

The three index mapping used according to the GOD methodology: (a) G - Groundwater confinement; (b) O - Overlying strata, and (c) D - Depth to the groundwater table.

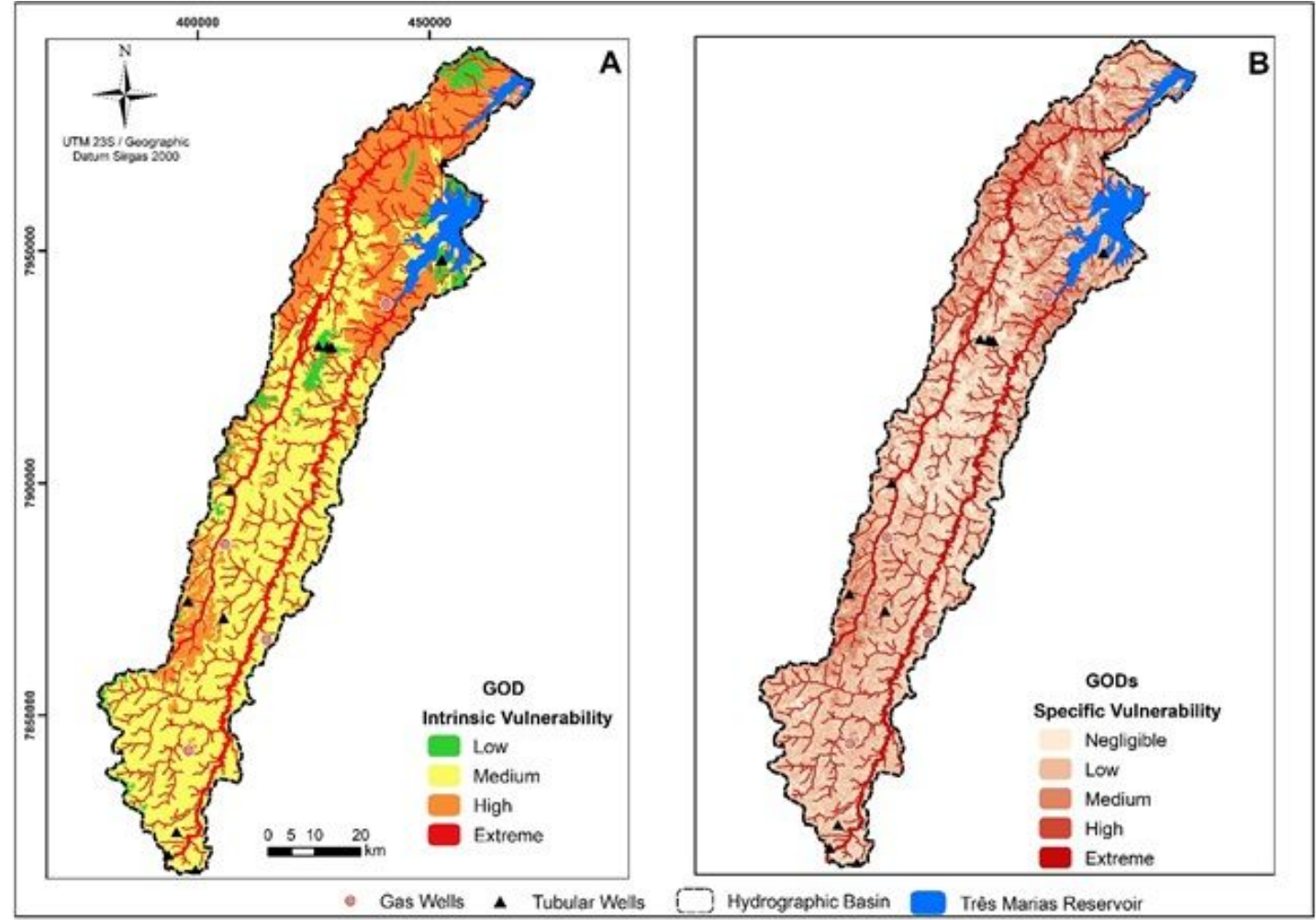

Figure 6

Intrinsic vulnerability mapping - GOD (A). Specific vulnerability mapping - GODs (B). 